\title{
Review \\ Developments in the scientific understanding of osteoporosis
} Nancy E Lane and Wei Yao

Aging Center, Medicine and Rheumatology, Department of Medicine, University of California at Davis Medical School, Sacramento, CA 95817, USA

Corresponding author: Nancy Lane, nelane@ucdavis.edu

Published: 19 May 2009

This article is online at http://arthritis-research.com/content/11/3/228

(C) 2009 BioMed Central Ltd
Arthritis Research \& Therapy 2009, 11:228 (doi:10.1186/ar2656)

osteoclast-mediated bone resorption, and a reversal period. Then there is a longer period of bone formation mediated by osteoblasts, followed by the full mineralization of the newly formed bone matrix [1-3]. There is now evidence to support that these bone cells communicate with each other and osteocytes embedded in the mineralized matrix. Apart from BMU cells, T lymphocytes, B lymphocytes, and neural cells also communicate with the bone cells [4-6]. This review is limited to the advances that have been made in our understanding of bone biology and will include the differentiation and local regulation of bone cells.

\section{Introduction}

Bone is a mineralized tissue that has recognized mechanical functions, including protection and support for the internal organs and for locomotion. Bone tissue is constantly 'turning over', allowing bone to repair itself, for instance after a fracture, and to adapt to the mechanical loads that are placed on it. In the adult skeleton, the rate of bone turnover, collagen matrix, structure, geometry, and density all combine to determine the bone's overall mechanical competence. Defects in these parameters can result in diseases such as osteoporosis, osteopetrosis, osteogenesis imperfecta, and Paget's disease $[1,2]$.

The dynamic nature of the skeleton is achieved by a process of bone remodeling. Bone is continuously replaced during adult life through tightly coupled bone resorption by osteoclasts and bone formation by osteoblasts, as well as osteocytes within the bone matrix and bone lining cells that cover the bone surface. The coordinated action of these cells is described as the 'basic multicellular unit' (BMU). Within the BMU cellular activity is coupled; in principle the amount of bone that is removed is replaced. The remodeling cycle occurs continuously at discrete sites throughout the skeleton in response to mechanical and metabolic influences. Remodeling starts with the initiation of osteoclast formation,

\section{Osteoblasts}

Our understanding of osteoblast differentiation and local regulation has increased over the past 10 years through the discovery of the canonical Wnt signaling pathway. The Wnt family of glycoproteins represents a major signaling pathway that is involved in cellular differentiation. Secreted Wnt proteins act on target cells by binding to the frizzled and lowdensity lipoprotein receptor-related protein (LRP) complex on the cell surface. The binding signal is transduced to intracellular proteins including dishelved, glycogen synthase kinase-3, axin, adenomatous polyposis coli, and $\beta$-catenin, which functions as a transcriptional regulator [7]. If $\mathrm{Wnt}$ proteins are not present, then glycogen synthase kinase-3 constitutively phosphorylates the $\beta$-catenin protein, which leads to degradation and this provides a mechanism to maintain a low concentration of $\beta$-catenin in the cytoplasm of the cell. The binding of Wnt proteins act on the target cell by binding to frizzled receptors and their co-receptor LRP5/6 that stabilizes cytoplasmic $\beta$-catenin protein, which in turn translocates to the nucleus and activates the transcription of target genes via transcription factors including lymphoid enhancer-binding factor and T-cell factors $[8,9]$. There are also antagonists of the Wnt signaling pathway, which include secreted frizzled-related protein (SFRP) 1, Wnt inhibitory

$\mathrm{BMU}=$ basic multicellular unit; BSAP = bone-specific alkaline phosphatase; CTX = C-telopeptide crosslink of type I collagen; DKK = dickkopf; FLS = fibroblast-like synoviocyte; hPTH(1-34) = human PTH(1-34); IL = interleukin; LRP = low-density lipoprotein receptor-related protein; NTX = $\mathrm{N}$-telopeptide crosslink of type I collagen; OPG = osteoprotegerin; OPPG = osteoporosis pseudoglioma syndrome; P1NP = amino-terminal propeptide of type I procollagen; $\mathrm{PTH}=$ parathyroid hormone; RA = rheumatoid arthritis; RANKL = receptor activator of nuclear factor- $\mathrm{KB}$ ligand; $\mathrm{SFRP}=$ secreted frizzled-related protein; $\mathrm{TNF}=$ tumor necrosis factor; $\mathrm{WIF}=\mathrm{Wnt}$ inhibitory factor. 
factor (WIF)-1, dickkopf (DKK)-1, and sclerostin; these either bind to LRP5/6 or inactive LRP5/6, such that the Wnt signaling is stopped.

The Wnt signaling pathway is well known in developmental biology and growth, and metastases of cancer, but the connection to the skeleton was not initially clear $[10,11]$. However, a family was described that had a loss of function of Lrp5, which was known to be a co-receptor in the Wnt signaling pathway, members of which had low bone density (osteoporosis pseudoglyoma syndrome); another family was described with a gain of function of Lrp5, resulting in a high bone mass phenotype [12-14]. These clinical observations have been confirmed in studies in which mice were generated that exhibited either no Lrp5 function or increased Lrp5 function; bone mass findings were similar [12-18]. Also, mutations in the gene encoding sclerostin (Sost), an antagonist of Wnt signaling, resulted in a high bone mass disease (van Buchem disease or sclerostosis syndrome) [19-22]. Over-expression of DKK-1 induces osteopenia in mice [23], whereas deletion of a single allele of the $D K K-1$ gene leads to an increase in bone formation and bone mass [24]. Increased production of DKK-1 by plasmacytoid cells in patients with multiple myeloma are responsible for the osteocytic lesions observed in that disease [25,26]. Also, in patients with prostate and breast cancer bone metastasis, DKK-1 production has been reported to be responsible for development of osteolytic bone lesions in these diseases $[27,28]$.

The pathogenesis of glucocorticoid-induced osteoporosis may also involve increased expression of DKK-1, which suppresses osteoblastic differentiation through the Wnt pathway [29]. We conducted a microarray on whole bone extracts from mice that were treated with glucocorticoids for 56 days and found that Wnt antagonists - including DKK-1, sclerostin, and WIF-1 - were upregulated from days 28 to 56 [30]. Thus, suppression of Wnt signaling may be responsible for part of the pathogenesis of prolonged suppression of bone formation after glucocorticoid administration. Concurrent treatment of glucocorticoid-treated mice with parathyroid hormone (PTH) for 28 days reversed the elevation of DKK-1 and was associated with increased osteogenesis.

\section{Secreted frizzled related protein-1 and bone formation}

SFRP1 is a soluble inhibitor of Wnt signaling. Its role in bone formation is now just being discovered. Adult mice deficient in SFRP1 exhibited increased trabecular bone accrual and resistance to age-related bone loss. Mice with over-expression of sFRP1 (sFRP1-transgenic mice) exhibited osteopenia with lower osteoblastogenesis and bone formation, with males being more severely affected than females [31]. The reduced bone mass in sFRP1-transgenic mice was accompanied by evidence of reduced osteogenesis, with reduced alkaline phosphatase and mineralized nodule formation in vitro. In vitro osteoclastogenesis was also higher in sFRP1transgenic mice. $s F R P 1$-transgenic mice treated for 2 weeks with high-dose human $\mathrm{PTH}(1-34)$ (hPTH[1-34]) exhibited almost no increase in bone mass compared with wild-type mice [31]. SFRP1 over-expression appears to counteract the $\mathrm{PTH}$-induced increases in osteoblast differentiation and activity. Expression levels of osteogenic genes (RUNX2 and the genes encoding osterix and osteocalcin) were lower in sFRP1-transgenic mice treated with $\mathrm{PTH}$, as compared with levels in wild-type mice. These data suggest that this Wnt signaling inhibitor not only reduced osteogenesis but also appeared to augment osteoclastogenesis, possibly through increased production of receptor activator of nuclear factor$\kappa \mathrm{B}$ ligand (RANKL) by pre-osteoblasts and reduced production of osteoprotegerin (OPG) by mature osteoblasts.

\section{New studies that may expand our understanding of the Wnt signaling pathway and bone formation}

The discovery of mutations in the Wnt pathway - specifically mutations in LRP5, which is the co-receptor for Wnt proteins and is associated with a phenotype of low bone mass, namely osteoporosis pseudoglioma syndrome (OPPG) - led to the view that canonical Wnt signaling through the cell surface receptor LRP5 or LRP6 controlled osteoblast formation or action. Osteogenesis is stimulated by canonical Wnt signaling in a number of ways (Figure 1). In the early stages of differentiation of mesenchymal stem cells to osteoblast precursors, Wnt signaling agonists direct these precursor cells toward osteogenesis and prevent the alternative differentiation of these stem cells toward adipocytes and chondrocytes $[32,33]$ through translocation of $\beta$-catenin to the nucleus and activation of transcription of genes involved in osteogenesis [34-36]. Findings in Lrp5 knockout mice support a further role for Wnt signaling in osteoblast function, because these mice exhibited reduced bone matrix deposition [37]. Over-expression of $\beta$-catenin can result in increased collagen production [38]. Also, another osteogenic effect of Wnt signaling, namely that it reduced apoptosis of osteoblasts and osteocytes, has been reported [35].

Despite the strong evidence to support the role played by LRP5 or LRP6 in bone formation, the evidence to support canonical Wnt signaling in osteoblasts was less clear. Mice null for Lrp5 did have low bone mass, which is similar to the clinical phenotype of OPPG. However, in mice null for $\beta$ catenin, mature osteoblasts had a normal phenotype but exhibited increased osteoclastogenesis, which did not support a role for $\beta$-catenin in osteogenesis [37]. This led to the hypothesis that LRP5 may control bone formation independent of $\mathrm{Wnt} / \beta$-catenin signaling.

Investigators conducted microarray analyses of bone and other organ tissues from Lrp5 knockout mice and found that the gene encoding tryptophan hydroxylase (Tph1), a ratelimiting enzyme involved in serotonin synthesis, was highly 


\section{Figure 1}

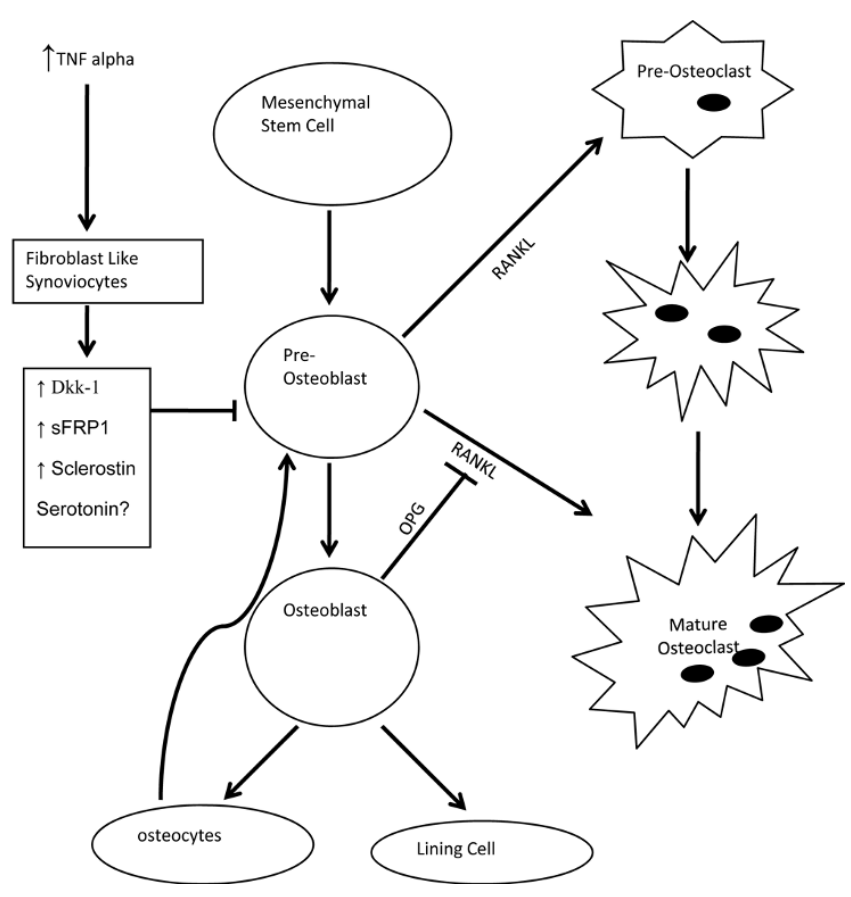

Pathways for osteogenesis and osteoclastogenesis. Osteoblasts mature from mesenchymal stem cells to preosteoblasts. The Wnt signaling pathway antagonists (DKK-1, sclerostin, and SFRP1) and serotonin all inhibit osteogenesis. A number of cell types can synthesize Wnt signaling antagonists. Fibroblast-like synoviocytes from rheumatoid arthritis patients after stimulation with TNF- $\alpha$, and myeloma cells synthesize DKK-1 and osteocytes synthesize sclerostin. Osteoblasts also now are known to be the main controllers of osteoclastogenesis through the production of RANKL by preosteoblast cells. The antagonist of RANKL, OPG, is produced by mature osteoblasts and prevents RANKL from binding to its receptor, RANK, so that osteoclast maturation and activity are inhibited. DKK, dickkopf; OPG, osteoprotegerin; RANKL, receptor activator of nuclear factor-KB ligand; SFRP, secreted frizzled-related protein; TNF, tumor necrosis factor.

expressed in the enterochromaffin cells of the duodenum, and serum serotonin levels were high compared with those in wild-type control animals [11]. The investigators went on to demonstrate that LRP5 augmentation of bone formation and accrual of bone mass appeared to be through the inhibition of Tph1 expression and serotonin synthesis in enterochromaffin cells in the duodenum. Serotonin appears to inhibit osteoblast proliferation by binding to its receptor, 5-hydroxytryptamine receptor $1 \mathrm{~B}$, on the osteoblast surface [31]. The investigators further demonstrated that the animals with mutations in Lrp5 (OPPG) have high circulating serotonin levels [11]. A number of studies have reported that patients receiving serotonin re-uptake inhibitors have low bone mass compared with age-matched control individuals, suggesting that if circulating levels of serotonin are increased in these patients then they may have reduced bone formation $[39,40]$.
Although more work is needed in this area, these experiments have increased our understanding of how LRP5 may work to increase osteoblast proliferation, and provide new data to support a mechanism by which intestine and bone may communicate. A few years ago, the discovery of LRP5 as a disease with a clinical phenotype of low bone mass was the beginning of the research directed at elucidating how the Wnt signaling pathway regulates bone formation. However, this new work by Yadav and coworkers [11] suggests that the influence of Wnt/LRP5 may be indirect and may partially work through the intestine.

\section{Osteocytes: key regulators of the skeletal response to mechanical loading and bone formation}

Over the past 10 years, our scientific understanding of osteocytes and their role in bone metabolism has significantly increased. The osteocyte, which is the most abundant cell type in bone, resides in the lacuna/canalicular system, and strong evidence supports its role in the control of local bone remodeling. These cells are nonproliferative terminally differentiated cells of the osteoblast lineage [41]. They form an extensive network of canaliculi that connect these cells to each other, blood vessels, and the bone surface. The surface area of the lacuna/canalicular system is large - more than 100 times that of the trabecular bone surface [41]. The canalicular system of communication for the osteocytes is similar to that of the nervous system, in that there are a large number of low activity cells connected through the canaliculi, and it is hypothesized to be an efficient way to transmit signals over long distances [42]. The osteocytes are also surrounded within their lacunae by proteoglycans, which are hypothesized to assist in the amplification of fluid flow-derived mechanical signals. Each osteocyte has a cilium that extends from its cell cytoplasm, which may also translate the fluid flow signal to the osteocyte [41].

It has long been known that mechanical stress induced by weight-bearing exercise increases osteoblast activity. However, the absence of mechanical stimulation resulting from immobilization or bed rest can cause rapid bone loss [41]. Based on these findings, it has been postulated that osteocytes are mechano-sensitive cells and that the lacunae/ canaliculi carry the signaling molecules that are responsible for maintenance of bone structure and mass $[41,43]$. The model has been proposed to explain how mechanical loading can induce the biochemical transmission that promotes bone formation and remodeling.

During the 1960s a phenomenon was reported that was referred to as 'osteocytic osteolysis', in which large osteocyte lacunae were observed within the cortex and the trabeculae, in patients with hypophosphotemic rickets [44-47]. This observation that the osteocyte can modify its microenvironment was not confirmed by other laboratories and was not validated until very recently. Our laboratory group studied 
a mouse model of glucocorticoid-induced bone loss and reported some novel observations about osteocytes $[30,48,49]$. Glucocorticoid treatment initially increased osteoclast maturation and activity, and this was followed by delayed but prolonged suppression of bone formation. Trabecular bone loss with glucocorticoid treatment was about $20 \%$ over 21 days. Analysis of gene expression from the bone revealed elevation of osteoclastogenic genes for the first 7 days of glucocorticoid treatment, followed by suppression of osteogenic genes, and an increase in dentin matrix protein-1, sclerostin, and other Wnt signaling inhibitors (DKK1 and WIF). Interestingly, atomic force microscopy and raman microscopy of the trabecular surface from the individual trabeculae in glucocorticoid-treated mice demonstrated enlarged osteocyte lacunae and areas of low elastic modulus and low bone mineral $[30,48,49]$. These findings suggested that glucocorticoid treatment was associated with changes in both bone remodeling and osteocyte metabolism, which may result in localized changes in bone strength at the bone surface and within bone tissue; this may begin to explain the increased bone fragility in patients receiving glucocorticoids.

That the osteocyte can modify its microenvironment and enlarge the lacunae has been observed in the settings of prolonged estrogen deficiency in rats, hypophosphatemic rickets in mice, and lactating mice [41-43]. However, we are not yet able to determine the stimuli that are responsible for the osteocyte's action. Currently, the three clinical conditions associated with enlarged osteocyte lacunae - namely hypophosphotemic rickets, lactation in mice, and glucocorticoids in mice - suggest that the lacunae may enlarge and contract depending on the need to mobilize calcium from the skeleton. Estimates of surface-based bone remodeling indicate that the number of osteoclasts that can occupy the bone surface is insufficient to maintain calcium balance in most rodents and animals. It is possible that the osteocyte, under certain physiologic conditions, can participate in mobilizing calcium from the skeleton to maintain calcium balance [50].

\section{The functional role of the osteocyte in bone}

The recent discovery of sclerostin is an example of an osteocyte-derived signal that can inhibit bone formation. Sclerostin is a Wnt signaling antagonist and is known to inhibit osteogenesis [41,51]. Sclerostin gene expression has been reported to be responsive to mechanical stimulation, PTH treatment, and glucocorticoid treatment [49,52,53]. Recent work has shown that when osteocytes produce sclerostin, it moves through the canaliculi into the bone marrow and appears to reduce osteoblast differentiation and bone formation through its inhibition of frizzled/LRP5/6 transmembrane signaling. Treatment with hPTH(1-34), an anabolic agent that stimulates bone formation, has been found to reduce sclerostin expression in osteocytes in animal models [43,49,52,53]. Although rare, clinically observed diseases of sclerostin production - sclerosteosis and Van Buchem disease - are high bone mass disorders that have been linked to deficiencies in the SOST gene (which encodes sclerostin). Mice that are null for sclerostin have very high bone mass phenotypes [54], and treatment of osteopenic mice with anti-sclerostin antibody restored bone mass compared with that in control animals [55].

Because sclerostin is produced in adults, primarily in osteocytes, and appears to inhibit bone formation through inhibition of Wnt signaling, this aspect of osteocyte biology may be very important for the development of an anabolic agent to treat osteoporosis. In a phase I clinical study in postmenopausal women treated with a number of doses of a sclerostin antibody, it was found that 85 days after the study subjects received the anti-sclerostin antibody, they had a dose-related increase of $60 \%$ to $100 \%$ in bone formation markers amino-terminal propeptide of type I procollagen (P1NP) and bonespecific alkaline phosphatase (BSAP), and a trend toward a dose-related decrease in a serum marker of bone resorption, namely $\mathrm{C}$-telopeptide crosslink of type I collagen (CTX) [56]. Currently, phase II clinical trials with a monoclonal antibody directed against sclerostin are underway. This therapy, directed at the inhibition of osteocyte-derived sclerostin, may be a potential new anabolic therapy for patients with osteoporosis.

\section{Recent developments in our understanding of osteoclastogenesis}

Our understanding of the activation process in osteoclasts represents one of the most important discoveries in bone biology over the past 10 years. In summary, the activator of resorption, known as RANKL, is expressed by osteoblasts and binds to its receptor RANK on osteoclasts [57-59]. RANKL is a member of the tumor necrosis family, and it is the most important of the cytokines involved in the final stages of osteoclast maturation and activity.

Osteoclasts are derived from precursor cells belonging to the monocyte/macrophage lineage from bone marrow. In vitro studies have found that RANKL is expressed on immature osteoblasts in the presence of macrophage colony stimulating factor, activates RANK, induces the formation of osteoclasts through recruitment of osteoclast precursors in the marrow, and promotes their differentiation and fusion into multinucleated osteoclasts, which are responsible for resorption. Several cytokines are involved in the events that also promote osteoclast development, including macrophage colony-stimulating factor, which is essential for RANKL's action in osteoclastogenesis; IL-1, which is derived from osteoblasts and is a potent stimulator of RANKL; and IL-6, which is produced by osteoclasts in response to PTH and 1,25-dihydroxyvitamin D. T lymphocytes that produce IL-15 and IL-17 are also reported to support osteoclastogenesis. Although there are a number of systemic factors that initiate osteoclastogenesis, they all appear to work via the final common pathway of increasing production of RANKL by osteoblasts [59]. 
The action of RANKL on osteoclasts is opposed by the soluble receptor OPG, which is secreted by osteoblasts, and stromal cells, which belong to the tumor necrosis factor (TNF) receptor family $[59,60]$. The actions of RANKL and OPG on osteoclastogenesis were demonstrated in a number of experiments in mice. Mice over-expressing OPG had high bone mass and those without OPG had very low bone mass [61]. Treatment of estrogen-deficient mice with a monoclonal antibody to OPG prevented bone loss $[59,60]$, and mice without RANKL had high bone mass [62]. These important studies demonstrated that the RANKL/RANK/OPG system is a key regulator of osteoclast maturation and activity [59].

The preclinical work quickly led to clinical studies that initially evaluated OPG but then switched to an antibody to RANKL. The antibody to RANKL is now named AMG 162 or denosumab. A phase I clinical study demonstrated efficacy similar to that with OPG in terms of rapidly reducing biochemical markers of bone turnover [63]. Clinical studies conducted to determine whether denosumab can prevent and treat osteoporosis have reported this agent to be very effective, and within 12 to 24 months it may be approved for the treatment of osteoporosis [64]. In addition, rheumatoid arthritis (RA) patients on chronic stable methotrexate therapy with prevalent bone erosions were randomly assigned to treatment with AMG 162 or placebo for 1 year; the group treated with AMG 162 had significantly less structural deterioration than in the placebo group [65]. These data suggest that a medication that is a potent inhibitor of osteoclast maturation and activity, such as AMG 162, may have utility in the prevention of generalized and localized bone loss and structural deterioration in patients with RA.

One other important discovery about RANKL and osteoclastogenesis is related to the action of $\mathrm{hPTH}(1-34)$. Treatment of osteopenic animals and osteoporotic women and men is associated with a rapid increase in new bone formation, with biochemical markers of bone formation (P1NP, BSAP, and osteocalcin) increasing from baseline levels within a few weeks of therapy. This is followed by a slower increase in levels of bone resorption markers (CTX and C-telopeptide crosslink of type I collagen [NTX]). At about 6 months of treatment with hPTH(1-34), bone formation and resorption markers are elevated to around the same level [66]. The mechanism responsible for the increased bone resorption with hPTH(1-34) treatment was not immediately clear. However, when the PTH receptor was located on the osteoblast, we determined that PTH treatment augmented the maturation of osteoblasts to make bone, but also stimulated osteoblasts to produce RANKL that augmented osteoclastogenesis [67]. The need for osteoclastogenesis it not completely clear but it may be that the bone resorption allows osteoblast growth factors stored within the bone matrix to be released into the bone marrow microenvironment (insulin-like growth factor-l, fibroblast growth factor-2 and transforming growth factor- $\beta$ ), and these growth factors may provide continual stimulation of osteoblast differentiation and activity [68]. Support for this observation comes from clinical studies in which the bone anabolic effects of PTH appeared to be blunted in the lumbar spine when PTH and a potent anti-resorptive agent were used in combination in both postmenopausal women and men with osteopenia $[69,70]$.

\section{Osteoimmunology and the involvement of the Wnt signaling pathway in inflammatory bone destruction}

$\mathrm{RA}$ is characterized as an inflammatory arthritis in which joint inflammation results in bone deterioration. In RA, the proinflammatory cytokine TNF- $\alpha$ is critical in driving inflammatory disease. TNF is mainly produced by macrophages, fibroblasts and dendritic cells, and in synovitis associated with RA, and it is responsible for activating osteoclastogenesis. Bone formation is affected in RA, and until very recently it was believed that TNF production reduced osteogenesis in the presence of the inflammatory arthritis.

Diarra and coworkers utilized a transgenic mouse that overexpressed TNF- $\alpha$ [71], which exhibits changes in the joints that are similar to those observed in human RA. It had been known for a few years that Wnt signaling proteins are expressed in inflamed rheumatoid joints, and Diarra and coworkers hypothesized that Wnt activation of osteogenesis might be inhibited by Wnt antagonists in the inflamed joint. They focused their work on DKK-1, which had been reported to be expressed in inflamed erosive joints [72]. The investigators treated TNF-transgenic mice and two other mouse arthritis models with an antibody to DKK-1 and TNF, and demonstrated that these antibodies protected against bone erosions, thereby preventing structural deterioration. They also observed that osteophyte formation was more pronounced in the arthritic mice treated with the anti-DKK-1 antibody, and no effect on inflammation was observed. These observations led the investigators to conclude that inhibition of DKK-1 leads to increased osteogenesis and less osteoclastogenesis, with the latter being an indirect effect mediated by mature osteoblasts producing more OPG and less RANKL by pre-osteoblasts.

This study by Diarra and coworkers [71] was a landmark study, because they demonstrated that DKK-1, the Wnt signaling antagonist, can connect the immune system to bone metabolism. The paradigm now is that the pro-inflammatory cytokine TNF- $\alpha$ induces the expression of DKK-1 from fibroblasts such as synoviocytes and other cells within the synovium, such that bone formation is inhibited in the presence of inflammatory arthritis. In addition, by preventing osteoblast maturation, pre-osteoblasts are able to produce more RANKL; and with less mature osteoblasts, less OPG is synthesized, which results in increased osteoclastogenesis [73].

Another group of investigators carried this work further and collected synovium from patients with RA, and then treated 


\section{The Scientific Basis of Rheumatology: A Decade of Progress}

This article is part of a special collection of reviews, The Scientific Basis of Rheumatology: A Decade of Progress, published to mark Arthritis Research \& Therapy's 10th anniversary.

Other articles in this series can be found at: http://arthritis-research.com/sbr

these patients with TNF and found that in fibroblast-like synoviocytes (FLSs) gene expression of DKK-1 increased more than threefold, followed by modest elevations in IL-1 and IL-6 (as measured by quantitative reverse transcription polymerase chain reaction) [74]. To translate this observation to RA patients, they collected serum and synovial samples and they found that DKK-1 was elevated in serum and that DKK-1 expression was increased in FLS samples. However, DKK-1 expression was decreased in synovial samples from osteoarthritis patients [74].

These studies are seminal to our understanding of inflammatory bone loss and lead us to hypothesize that, with the TNF- $\alpha$-induced synovitis that accompanies RA, DKK-1, $\mathrm{IL}-1$, and IL- 6 are produced that are able to inhibit osteogenesis and accelerate osteoclastogenesis. When TNFtransgenic mice were treated with inhibitors of TNF and DKK-1, these agents prevented nearly all of the structural deterioration of bone and cartilage that accompanies RA [72]. In RA patients it is possible that treatment with potent TNF-blocking agents reduce both the synovitis and the production of DKK-1, IL-1, and IL- 6 by FLSs, thereby preventing some of the structural deterioration in the joints. These studies suggest that the Wnt signaling pathway, which is important in joint development, is also important in diseases of the joint. Further understanding of the Wnt signaling pathway in bone metabolism will provide new opportunities for treatment of RA.

\section{Conclusion}

This review highlights the developments in out scientific understanding of osteoporosis in the past 10 years. We believe, in the next 10 years, scientific advances in osteoporosis will improve both the prevention and treatment of this disease.

\section{Competing interests}

The authors declare that they have no competing interests.

\section{Acknowledgements}

This work was supported by NIH grants K24 AR04884, R01 AR043052, and the endowment for aging to Dr Lane.

\section{References}

1. Datta HK, Ng WF, Walker JA, Tuck SP, Varanasi SS: The cell biology of bone metabolism. J Clin Pathol 2008, 61:577-587.

2. Sims NA, Gooi JH: Bone remodeling: multiple cellular interactions required for coupling of bone formation and resorption. Semin Cell Dev Biol 2008, 19:444-451.

3. Lips P, Courpron P, Meunier PJ: Mean wall thickness of trabecular bone packets in the human iliac crest: changes with age. Calcif Tissue Res 1978, 26:13-17.

4. Gillespie MT: Impact of cytokines and T lymphocytes upon osteoclast differentiation and function. Arthritis Res Ther 2007, 9:103.

5. Horowitz MC, Lorenzo JA: B lymphocytes and the skeleton. Ann NYAcad Sci 2007, 1117:82-93.

6. Elefteriou F: Regulation of bone remodeling by the central and peripheral nervous system. Arch Biochem Biophys 2008, 473: 231-236.

7. Shahnazari M, Yao W, Corr M, Lane NE: Targeting the Wnt signaling pathway to augment bone formation. Curr Osteoporos Rep 2008, 6:142-148.

8. Huang $\mathrm{H}, \mathrm{He} \mathrm{X}$ : Wnt/beta-catenin signaling: new (and old) players and new insights. Curr Opin Cell Biol 2008, 20:119125.

9. Gordon MD, Nusse R: Wnt signaling: multiple pathways, multiple receptors, and multiple transcription factors. J Biol Chem 2006, 281:22429-22433

10. Vlad A, Rohrs S, Klein-Hitpass L, Muller O: The first five years of the Wnt targetome. Cell Signal 2008, 20:795-802.

11. Yadav VK, Ryu JH, Suda N, Tanaka KF, Gingrich JA, Schütz G, Glorieux FH, Chiang CY, Zajac JD, Insogna KL, Mann JJ, Hen R, Ducy P, Karsenty G: Lrp5 controls bone formation by inhibiting serotonin synthesis in the duodenum. Cell 2008, 135:825837.

12. Gong Y, Slee RB, Fukai N, Rawadi G, Roman-Roman S, Reginato $A M$, Wang $H$, Cundy T, Glorieux FH, Lev D, Zacharin M, Oexle K, Marcelino J, Suwairi W, Heeger S, Sabatakos G, Apte S, Adkins WN, Allgrove J, Arslan-Kirchner M, Batch JA, Beighton P, Black GC, Boles RG, Boon LM, Borrone C, Brunner HG, Carle GF, Dallapiccola B, De Paepe A, et al.: LDL receptor-related protein 5 (LRP5) affects bone accrual and eye development. Cell 2001, 107:513-523.

13. Boyden LM, Mao J, Belsky J, Mitzner L, Farhi A, Mitnick MA, Wu D, Insogna K, Lifton RP: High bone density due to a mutation in LDL-receptor-related protein 5. N Engl J Med 2002, 346:15131521

14. Little RD, Carulli JP, Del Mastro RG, Dupuis J, Osborne M, Folz C, Manning SP, Swain PM, Zhao SC, Eustace B, Lappe MM, Spitzer L, Zweier S, Braunschweiger K, Benchekroun Y, Hu X, Adair R, Chee L, FitzGerald MG, Tulig C, Caruso A, Tzellas N, Bawa A, Franklin B, McGuire S, Nogues X, Gong G, Allen KM, Anisowicz $A$, Morales AJ, et al:: A mutation in the LDL receptor-related protein 5 gene results in the autosomal dominant high-bonemass trait. Am J Hum Genet 2002, 70:11-19.

15. Akhter MP, Wells DJ, Short SJ, Cullen DM, Johnson ML, Haynatzki GR, Babij P, Allen KM, Yaworsky PJ, Bex F, Recker RR: Bone biomechanical properties in LRP5 mutant mice. Bone 2004 35:162-169.

16. Babij $P$, Zhao W, Small C, Kharode $Y$, Yaworsky PJ, Bouxsein ML, Reddy PS, Bodine PV, Robinson JA, Bhat B, Marzolf J, Moran RA, Bex F: High bone mass in mice expressing a mutant LRP5 gene. J Bone Miner Res 2003, 18:960-974.

17. Ferrari SL, Deutsch S, Baudoin C, Cohen-Solal M, Ostertag A, Antonarakis SE, Rizzoli R, de Vernejoul MC: LRP5 gene polymorphisms and idiopathic osteoporosis in men. Bone 2005, 37: 770-775

18. Semenov MV, He X: LRP5 mutations linked to high bone mass diseases cause reduced LRP5 binding and inhibition by SOST. J Biol Chem 2006, 281:38276-38284.

19. Balemans W, Ebeling M, Patel N, Van Hul E, Olson P, Dioszegi M, Lacza C, Wuyts W, Van Den Ende J, Willems P, Paes-Alves AF, Hill S, Bueno M, Ramos FJ, Tacconi P, Dikkers FG, Stratakis C, Lindpaintner K, Vickery B, Foernzler D, Van Hul W: Increased bone density in sclerosteosis is due to the deficiency of a novel secreted protein (SOST). Hum Mol Genet 2001, 10:537543.

20. Balemans W, Foernzler D, Parsons C, Ebeling M, Thompson A, Reid DM, Lindpaintner K, Ralston SH, Van Hul W: Lack of asso- 
ciation between the SOST gene and bone mineral density in perimenopausal women: analysis of five polymorphisms. Bone 2002, 31:515-519.

21. Balemans W, Patel N, Ebeling M, Van Hul E, Wuyts W, Lacza C, Dioszegi M, Dikkers FG, Hildering P, Willems PJ, Verheij JB, Lindpaintner K, Vickery B, Foernzler D, Van Hul W: Identification of a $52 \mathrm{~kb}$ deletion downstream of the SOST gene in patients with van Buchem disease. J Med Genet 2002, 39:91-97.

22. Brunkow ME, Gardner JC, Van Ness J, Paeper BW, Kovacevich BR, Proll S, Skonier JE, Zhao L, Sabo PJ, Fu Y, Alisch RS, Gillett L, Colbert T, Tacconi P, Galas D, Hamersma H, Beighton P, Mulligan J: Bone dysplasia sclerosteosis results from loss of the SOST gene product, a novel cystine knot-containing protein. Am J Hum Genet 2001, 68:577-589.

23. Li J, Sarosi I, Cattley RC, Pretorius J, Asuncion F, Grisanti M, Morony S, Adamu S, Geng Z, Qiu W, Kostenuik P, Lacey DL, Simonet WS, Bolon B, Qian X, Shalhoub V, Ominsky MS, Zhu Ke $\mathrm{H}$, Li X, Richards WG: Dkk1-mediated inhibition of Wnt signaling in bone results in osteopenia. Bone 2006, 39:754-766.

24. Morvan F, Boulukos K, Clément-Lacroix P, Roman Roman S, SucRoyer I, Vayssière B, Ammann P, Martin P, Pinho S, Pognonec P, Mollat P, Niehrs C, Baron R, Rawadi G: Deletion of a single allele of the Dkk1 gene leads to an increase in bone formation and bone mass. J Bone Miner Res 2006, 21:934-945.

25. Yaccoby S, Ling W, Zhan F, Walker R, Barlogie B, Shaughnessy JD, Jr.: Antibody-based inhibition of DKK1 suppresses tumorinduced bone resorption and multiple myeloma growth in vivo. Blood 2007, 109:2106-2111.

26. Qiang YW, Chen Y, Stephens O, Brown N, Chen B, Epstein J, Barlogie B, Shaughnessy JD Jr: Myeloma-derived Dickkopf-1 disrupts Wnt-regulated osteoprotegerin and RANKL production by osteoblasts: a potential mechanism underlying osteolytic bone lesions in multiple myeloma. Blood 2008, 112: 196-207.

27. Hall CL, Keller ET: The role of Wnts in bone metastases. Cancer Metastasis Rev 2006, 25:551-558.

28. Voorzanger-Rousselot N, Goehrig D, Journe F, Doriath V, Body JJ, Clezardin P, Garnero P: Increased Dickkopf-1 expression in breast cancer bone metastases. Br J Cancer 2007, 97:964970.

29. Hurson CJ, Butler JS, Keating DT, Murray DW, Sadlier DM, O'Byrne JM, Doran PP: Gene expression analysis in human osteoblasts exposed to dexamethasone identifies altered developmental pathways as putative drivers of osteoporosis. BMC Musculoskelet Disord 2007, 8:12.

30. Yao W, Cheng Z, Busse C, Pham A, Nakamura MC, Lane NE: Glucocorticoid excess in mice results in early activation of osteoclastogenesis and adipogenesis and prolonged suppression of osteogenesis: a longitudinal study of gene expression in bone tissue from glucocorticoid-treated mice. Arthritis Rheum 2008, 58:1674-1686.

31. Yao W, Cheng Z, Busse C, Pham A, LANE N: Overexpression of secreted frizzled-related protein 1 inhibits bone formation and attenuates PTH bone anabolic effects [abstract]. J Bone Miner Res 2008, 23(suppl 1):S29.

32. Blair H, Sun L, Kohanski RA: Balanced regulation of proliferation, growth, differentiation, and degradation in skeletal cells. Ann N Y Acad Sci 2007, 1116:165-173.

33. Takada I, Suzawa M, Matsumoto K, Kato S: Suppression of PPAR- $\gamma$ transactivation switches cell fate of bone marrow stem cells from adipocytes into osteoblasts. Ann N Y Acad Sci 2007, 1116:182-195.

34. Almeida M, Han L, Bellido T, Manolagas SC, Kousteni S: Wnt proteins prevent apoptosis of both uncommitted osteoblast progenitors and differentiated osteoblasts by beta-catenindependent and -independent signaling cascades involving Src/ERK and phosphatidylinositol 3-kinase/AKT. J Biol Chem 2005, 280:41342-41351.

35. Baron R, Rawadi G: Targeting the Wnt/beta-catenin pathway to regulate bone formation in the adult skeleton. Endocrinology 2007, 148:2635-2643.

36. Baron R, Rawadi G, Roman-Roman S: Wnt signaling: a key regulator of bone mass. Curr Top Dev Biol 2006, 76:103-127.

37. Holmen SL, Giambernardi TA, Zylstra CR, Buckner-Berghuis BD, Resau JH, Hess JF, Glatt V, Bouxsein ML, Ai M, Warman ML, Williams BO: Decreased BMD and limb deformities in mice carrying mutations in both Lrp5 and Lrp6. J Bone Miner Res
2004, 19:2033-2040.

38. Cheon SS, Cheah AY, Turley S, Nadesan P, Poon R, Clevers H, Alman BA: beta-Catenin stabilization dysregulates mesenchymal cell proliferation, motility, and invasiveness and causes aggressive fibromatosis and hyperplastic cutaneous wounds. Proc Natl Acad Sci USA 2002, 99:6973-6978.

39. Williams LJ, Henry MJ, Berk M, Dodd S, Jacka FN, Kotowicz MA, Nicholson GC, Pasco JA: Selective serotonin reuptake inhibitor use and bone mineral density in women with a history of depression. Int Clin Psychopharmacol 2008, 23:8487.

40. Haney EM, Chan BK, Diem SJ, Ensrud KE, Cauley JA, BarrettConnor E, Orwoll E, Bliziotes MM: Association of low bone mineral density with selective serotonin reuptake inhibitor use by older men. Arch Intern Med 2007, 167:1246-1251.

41. Noble BS: The osteocyte lineage. Arch Biochem Biophys 2008, 473:106-111.

42. Laughlin SB, de Ruyter van Steveninck RR, Anderson JC: The metabolic cost of neural information. Nat Neurosci 1998, 1:3641.

43. Keller $\mathrm{H}$, Kneissel M: SOST is a target gene for PTH in bone. Bone 2005, 37:148-158.

44. Belanger LF, Narbaitz R: The mecanism of cementing line formation in the bones of cestrum-fed chicks. Rev Can Biol 1978, 37:5-14.

45. Drueke T, Bordier PJ, Man NK, Jungers P, Marie P: Effects of high dialysate calcium concentration on bone remodelling, serum biochemistry, and parathyroid hormone in patients with renal osteodystrophy. Kidney Int 1977, 11:267-274.

46. Wright $\mathrm{PH}$, Jowsey JO, Robb RA: Osteocyte lacunar area in normal bone, hyperparathyroidism, renal disease, and osteoporosis. Surg Forum 1978, 29:558-559.

47. Belanger LF: Osteocytic osteolysis. Calcif Tissue Res 1969, 4: 1-12.

48. Lane NE, Yao W, Balooch M, Nalla RK, Balooch G, Habelitz S, Kinney JH, Bonewald LF: Glucocorticoid-treated mice have localized changes in trabecular bone material properties and osteocyte lacunar size that are not observed in placebotreated or estrogen-deficient mice. J Bone Miner Res 2006, 21:466-476.

49. Yao W, Cheng Z, Pham A, Busse C, Zimmermann EA, Ritchie $\mathrm{RO}$, Lane NE: Glucocorticoid-induced bone loss in mice can be reversed by the actions of parathyroid hormone and risedronate on different pathways for bone formation and mineralization. Arthritis Rheum 2008, 58:3485-3497.

50. Teti $A$, Zallone A: Do osteocytes contribute to bone mineral homeostasis? Osteocytic osteolysis revisited. Bone 2009, 44: 11-16.

51. Noble BS, Peet N, Stevens HY, Brabbs A, Mosley JR, Reilly GC, Reeve J, Skerry TM, Lanyon LE: Mechanical loading: biphasic osteocyte survival and targeting of osteoclasts for bone destruction in rat cortical bone. Am J Physiol Cell Physiol 2003, 284:C934-C943.

52. Balemans W, Piters E, Cleiren E, Ai M, Van Wesenbeeck L, Warman ML, Van Hul W: The binding between sclerostin and LRP5 is altered by DKK1 and by high-bone mass LRP5 mutations. Calcif Tissue Int 2008, 82:445-453.

53. Bellido T: Downregulation of SOST/sclerostin by PTH: a novel mechanism of hormonal control of bone formation mediated by osteocytes. J Musculoskelet Neuronal Interact 2006, 6:358359.

54. Li X, Ominsky MS, Niu OT, Sun N, Daugherty B, D'Agostin D, Kurahara C, Gao Y, Cao J, Gong J, Asuncion F, Barrero M, Warmington K, Dwyer D, Stolina M, Morony S, Sarosi I, Kostenuik PJ, Lacey DL, Simonet WS, Ke HZ, Paszty C: Targeted deletion of the sclerostin gene in mice results in increased bone formation and bone strength. $J$ Bone Miner Res 2008, 23:860-869.

55. Li X, Ominsky MS, Warmington KS, Morony S, Gong J, Cao J, Gao Y, Shalhoub V, Tipton B, Haldankar R, Chen Q, Winters A, Boone T, Geng Z, Niu QT, Ke HZ, Kostenuik PJ, Simonet WS, Lacey DL, Paszty C: Sclerostin antibody treatment increases bone formation, bone mass and bone strength in a rat mode of postmenopausal osteoporosis. J Bone Miner Res 2009, 24: 578-588.

56. Padhi D, Stouch B, Jang G, Fang L, Darling M, Glise H, Robinson $M$, Harris S, Posvar E: Anti-sclerostin antibody increases markers of bone formation in healthy postmenopausal 
women [abstract]. J Bone Miner Res 2007, 22(suppl 1):S37.

57. Lacey DL, Timms E, Tan HL, Kelley MJ, Dunstan CR, Burgess T, Elliott R, Colombero A, Elliott G, Scully S, Hsu H, Sullivan J, Hawkins N, Davy E, Capparelli C, Eli A, Qian YX, Kaufman S, Sarosi I, Shalhoub V, Senaldi G, Guo J, Delaney J, Boyle WJ: Osteoprotegerin ligand is a cytokine that regulates osteoclast differentiation and activation. Cell 1998, 93:165-176.

58. Yasuda $H$, Shima N, Nakagawa N, Yamaguchi K, Kinosaki $M$, Mochizuki S, Tomoyasu A, Yano K, Goto M, Murakami A, Tsuda E, Morinaga T, Higashio K, Udagawa N, Takahashi N, Suda T: Osteoclast differentiation factor is a ligand for osteoprotegerin/osteoclastogenesis-inhibitory factor and is identical to TRANCE/RANKL. Proc Natl Acad Sci USA 1998, 95:35973602.

59. Gallagher JC: Advances in bone biology and new treatments for bone loss. Maturitas 2008, 60:65-69.

60. Simonet WS, Lacey DL, Dunstan CR, Kelley M, Chang MS, Lüthy R, Nguyen HQ, Wooden S, Bennett L, Boone T, Shimamoto G, DeRose M, Elliott R, Colombero A, Tan HL, Trail G, Sullivan J, Davy E, Bucay N, Renshaw-Gegg L, Hughes TM, Hill D, Pattison W, Campbell P, Sander S, Van G, Tarpley J, Derby P, Lee R, Boyle WJ: Osteoprotegerin: a novel secreted protein involved in the regulation of bone density. Cell 1997, 89:309-319.

61. Bucay N, Sarosi I, Dunstan CR, Morony S, Tarpley J, Capparelli C, Scully S, Tan HL, Xu W, Lacey DL, Boyle WJ, Simonet WS: osteoprotegerin-deficient mice develop early onset osteoporosis and arterial calcification. Genes Dev 1998, 12:12601268.

62. Kong YY, Yoshida H, Sarosi I, Tan HL, Timms E, Capparelli C, Morony S, Oliveira-dos-Santos AJ, Van G, Itie A, Khoo W, Wakeham A, Dunstan CR, Lacey DL, Mak TW, Boyle WJ, Penninger JM: OPGL is a key regulator of osteoclastogenesis, lymphocyte development and lymph-node organogenesis. Nature 1999, 397:315-323.

63. Bekker PJ, Holloway DL, Rasmussen AS, Murphy R, Martin SW, Leese PT, Holmes GB, Dunstan CR, DePaoli AM: A single-dose placebo-controlled study of AMG 162, a fully human monoclonal antibody to RANKL, in postmenopausal women. $J$ Bone Miner Res 2004, 19:1059-1066.

64. McClung MR, Lewiecki EM, Cohen SB, Bolognese MA, Woodson GC, Moffett AH, Peacock M, Miller PD, Lederman SN, Chesnut $\mathrm{CH}$, Lain D, Kivitz AJ, Holloway DL, Zhang C, Peterson MC, Bekker PJ; AMG 162 Bone Loss Study Group: Denosumab in postmenopausal women with low bone mineral density. $N$ Engl J Med 2006, 354:821-831.

65. Cohen SB, Dore RK, Lane NE, Ory PA, Peterfy CG, Sharp JT, van der Heijde D, Zhou L, Tsuji W, Newmark R: Denosumab treatment effects on structural damage, bone mineral density, and bone turnover in rheumatoid arthritis: a twelve-month, multicenter, randomized, double-blind, placebo-controlled, phase II clinical trial. Arthritis Rheum 2008, 58:1299-1309.

66. Lane NE, Sanchez S, Modin GW, Genant HK, Pierini E, Arnaud CD: Parathyroid hormone treatment can reverse corticosteroid-induced osteoporosis. Results of a randomized controlled clinical trial. J Clin Invest 1998, 102:1627-1633.

67. Buxton EC, Yao W, Lane NE: Changes in serum receptor activator of nuclear factor-kappaB ligand, osteoprotegerin, and interleukin-6 levels in patients with glucocorticoid-induced osteoporosis treated with human parathyroid hormone (1-34). $J$ Clin Endocrinol Metab 2004, 89:3332-3336.

68. Hurley $M$, Yao W, Lane NE: Changes in serum fibroblast growth factor 2 in patients with glucocorticoid-induced osteoporosis treated with human parathyroid hormone (1-34). Osteoporos Int 2005, 16:2080-2084.

69. Black DM, Greenspan SL, Ensrud KE, Palermo L, McGowan JA, Lang TF, Garnero P, Bouxsein ML, Bilezikian JP, Rosen CJ: The effects of parathyroid hormone and alendronate alone or in combination in postmenopausal osteoporosis. $N$ Engl J Med 2003, 349:1207-1215.

70. Finkelstein JS, Hayes A, Hunzelman JL, Wyland JJ, Lee H, Neer $\mathrm{RM}$ : The effects of parathyroid hormone, alendronate, or both in men with osteoporosis. N Engl J Med 2003, 349:1216-1226.

71. Diarra D, Stolina M, Polzer K, Zwerina J, Ominsky MS, Dwyer D, Korb A, Smolen J, Hoffmann M, Scheinecker C, van der Heide D, Landewe R, Lacey D, Richards WG, Schett G: Dickkopf-1 is a master regulator of joint remodeling. Nat Med 2007, 13:156163.
72. Keffer J, Probert L, Cazlaris H, Georgopoulos S, Kaslaris E, Kioussis D, Kollias G: Transgenic mice expressing human tumour necrosis factor: a predictive genetic model of arthritis. EMBO $J$ 1991, 10:4025-4031.

73. Goldring SR, Goldring MB: Eating bone or adding it: the Wnt pathway decides. Nat Med 2007, 13:133-134.

74. Corr $\mathrm{M}$ : Wnt-beta-catenin signaling in the pathogenesis of osteoarthritis. Nat Clin Pract Rheumatol 2008, 4:550-556. 